\title{
Meassevuring E-Service Quality, Satisfaction and Loyalty of Customer in the Online Channel of the Modern Retail
}

\author{
Cláudia Miranda Veloso¹, Daniel Magueta², Bruno Barbosa Sousa ${ }^{3}$ \\ And José Luís Carvalho ${ }^{4}$ \\ 1,2,4GOVCOPP; ESTGA; University of Aveiro, Águeda, Portugal \\ ${ }^{3}$ CiTUR; Polytechnic Institute of Cávado and Ave (IPCA), \\ Campus do IPCA. Vila Frescaínha S. Martinho. Barcelos, Portugal
}

Correspondence should be addressed to: Cláudia Miranda Veloso; cmv@ua.pt

Received date: 3 March 2020; Accepted date:16 July 2020; Published date: 2 September 2020

Academic Editor: Fernando Moreira

Copyright (c 2020. Cláudia Miranda Veloso, Daniel Magueta, Bruno Barbosa Sousa And José Luís Carvalho. Distributed under Creative Commons Attribution 4.0 International CC-BY 4.0

\begin{abstract}
Currently, the Internet has become a fitting channel for the trade of products. Gradually traditional and modern retail are using the online platform to sell their products. In this sense, the central aim of this study is to assess customer satisfaction and loyalty in relation to the ecommerce of the retail Auchan brand by analyzing the dimensions of the quality of the eservice, namely with regard to the placement and delivery of the order. The results obtained show that customers are satisfied with the online services of Auchan Famalicão (Portugal), showing greater preference and satisfaction with the Drive service. The contact attributes on the part of employees, compliance with the delivery deadline, comfort and convenience of the service stand out with high satisfaction. On the contrary, the design of the website, the ease of use of the website and the quality of the information available on the website, are the items with the worst evaluation by the customers of this retail brand. Regarding the dimensions of the e-service, the highest levels of satisfaction correspond to Guarantee, Fulfillment and Security, and the levels with the least satisfaction refer to reliability. Additionally, customers expressed strong loyalty to Auchan Famalicão's e-commerce. It is recommended that priorities should be established and intervene in terms of the quality of the e-service, particularly the dimensions with the worst evaluation in order to increase customer satisfaction and loyalty and, therefore, the performance and profitability of the Auchan Famalicão online channel.
\end{abstract}

Keywords: E-Service Quality, Customer Loyalty, E-commerce, Retail Industry.

Cite this Article as: Cláudia Miranda Veloso, Daniel Magueta, Bruno Barbosa Sousa And José Luís Carvalho (2020)," Meassevuring E-Service Quality, Satisfaction and Loyalty of Customer in the Online Channel of the Modern Retail", IBIMA Business Review, Vol. 2020 (2020), Article ID 531781, DOI: 10.5171/2020.531781 


\section{Introduction}

Electronic commerce is a distribution channel that is undergoing great expansion, being considered as the future of retail. Undoubtedly, e-commerce is an area of great importance and has a competitive advantage for organizations that have this distribution channel. Nevertheless, this channel is very competitive and presents some difficulties in retaining customers. According to several studies in the field of marketing (Abd-El-Salam, Shawky \& El-Nahas, 2013; Disfani et al., 2017; Durvasula \& Lysonski, 2010; Khare, Parveen \& Rai, 2010; Martinelli \& Balboni, 2012; Tang et al., 2015; Yu \& Ramanathan, 2012; Yuen \& Chan, 2010), to retain customers it is crucial to keep them satisfied, through the service provided, providing a pleasant and excellent shopping experience, and for that, it is essential to guarantee an effective logistical support, which ensures that the product reaches the customer at the location, time and quantity required by the customer.

The transactions of goods or products, through online means, have seen a considerable increase in recent years, being increasingly one of the methods chosen by customers for the purchase of goods or services. Online services show a gradual and fleeting increase in the share of sales volume, thus representing a channel to which retail companies should pay attention, importance and investment, given that it is a future trend for retail. Several companies that operate through traditional commerce (physical stores) complement their services, with online means, creating synergies between the two marketing methods, thus achieving greater market penetration, as well as satisfying a greater number of customers in a way more practical and more comprehensive. Organizations try to offer customers several advantages in order for them to opt for online services, but they have certain characteristics such as their intangible dimension, the impossibility of immediate possession of the products and contact with them. To this extent, despite certain impossibilities, e-retailers must present their customers with advantages that overcome these aspects, such as the convenience and convenience of the process, the reduction of time with the purchase act, as well as the fact that the process is simple and less stressful.

According to several studies (Galego, 2014; Hofacker et al., 2007; Rao et al., 2011; Wolfinbarger \& Gilly, 2003), customer satisfaction in online media is related to the maximization of the various logistical components inherent throughout the process: the place, the time and the availability of the products at the specified time and without great efforts for the customer. According to Zeithaml, Parasuraman and Malhotra (2002), the quality of the e-service is central to the success of online sales in any organization, being the main means of creating value and the main factors of customer retention.

There is a difficulty in determining the satisfaction factors, as well as the failures that customers perceive, that is, obtaining feedback from them. This fact makes it difficult and postpones the improvement of less satisfactory processes for customers, and organizations must find ways to analyze their customers' satisfaction with the various services they have available. To this extent, this study emerged to help the Auchan supermarket in Famalicão to assess customer satisfaction and loyalty in its electronic channels, with the central objective of determining which attributes of the e-service have the greatest influence on online customer satisfaction, as well as, factors that do not please customers and therefore should be improved in order to increase their satisfaction and, consequently, foster their loyalty. The paper is organized into three sections, in addition to this introduction and the main conclusions, as follows. On section two, a short review of the main literature on quality e-service, customer satisfaction and customer loyalty. After, on section three (methodology), the instrument to collect data is presented. That is, in this section, we describe the questionnaire used along with the formulation of the research hypotheses. Then, on section four, the data analysis and findings are presented. The 
paper finalizes with the discussion of findings and main conclusions of the research. This study is of particular interest for modern Portuguese distribution, given that most retail insignia are still taking their first steps on the online channel. Knowing in this study the dimensions of quality e-service that the Auchan customer is most satisfied with, as well as the dimensions that are determinants of customer satisfaction and loyalty online. It is also relevant for the development of the literature in the Portuguese traditional retail industry.

\section{Literature Review}

\section{E-service quality}

The e-service is defined as an action that brings value and benefits to the consumer through online platforms (Hofacker et al., 2007). The e-service encompasses the procedures on the website, allowing access to the consumer's purchase decision process, as well as order fulfillment. Eservice involves different levels of service from research to obtaining the product (Rabinovich, 2007). Zeithaml, Parasuraman and Malhotra (2002), developed e-servqual to measure the quality of the online service. According to them, e-servqual consists of seven dimensions, which are divided into a main service scale and a customer recovery service scale. The first four dimensions (efficiency, reliability, fulfillment, privacy and security) form the main e-servqual scale, being the means of evaluating customers' perceptions of the quality of service offered by online retailers. These dimensions include the criteria that customers use to evaluate the online service:

- Efficiency refers to the ability of customers to access the website, find the product and the information they want easily, as well as check out with minimum effort;

- Fulfillment incorporates the accuracy of service promises, having products in stock and selling the products in the promised time;
- Reliability is associated with the technical functioning of the website, mainly in relation to its activity and availability;

- The Privacy and Security dimension includes ensuring that shopping behavior data are not shared and that personal information is secure.

The e-service is characterized as an information system made available to customers in order to facilitate transactions through online means, which can create a competitive advantage if it occurs in an efficient way (Herington \& Weaven, 2009). For Parasuraman et al. (1988), service quality can be defined as the organization's ability to meet or exceed customer expectations and the difference between customer expectations and perceived service. When expectations are not met, the customer is dissatisfied with the quality of the service, and when these are exceeded, the customer is delighted. Briefly, the quality of the e-service results from the difference between expectations and consumer assessment (Parasuraman et al., 1988).

The quality of the e-service results from the processes made available to customers in order for them to purchase and receive the items in an effective and efficient manner, which is constantly being evaluated by consumers (Zeithaml et al., 2002). According to Wolfinbarger and Gilly (2003), the quality of the e-service is centered on the fulfillment process, in which the dimensions of stock availability, punctuality and reliability are inserted. Therefore, for e-fulfillment to have quality, it needs to be effective from the information process and transport of the stock to its delivery. According to Rao et al. (2011), there are three determining factors in the quality of the e-service, namely:

- Operational factors include parameters of the service that contribute to quality, productivity and efficiency, these can be characteristics of the service such as the location, time, availability and conditions of the product and fit into the fulfillment. 
- Relational factors are parameters such as proximity and understanding of the consumer, such as communication and responsibility.

- Logistic costs are parameters of the logistics service that allow the perception of consumer satisfaction regarding the price they pay and the cost that the logistics service requires, being able to establish standards of service quality levels.

\section{Customer Satisfaction}

Customer satisfaction should be the main concern of companies, as satisfied customers are loyal, being a primary step for the success of any organization (Mansano \& Gorni, 2014). Customer satisfaction with services occurs in the process of purchasing or providing a service and is influenced by individual emotional factors, the context and the costbenefit ratio (Moura, 2006). Satisfaction represents an appreciation on the part of customers in relation to a product or service and is influenced by the specific qualities of the products and / or services and their perception of quality (Zeithaml, Parasuraman \& Berry, 1994). The concept of satisfaction is formed by two distinct components, the structural part related to the tangible components and emotional satisfaction, which refers to the intangible components, such as the company's image. The emotional component of customer satisfaction is related to the subtraction of expectations with the perceived perception. Perception is a value judgment based on the senses, but with a lot of emotional content (Huete, 1998). There is a strong link between customer satisfaction and service quality, a factor that makes it possible to determine higher prices. Service quality consists of responding to customers' needs and expectations (Vavra, 1996). Customer satisfaction results from a comparison between perceived performance and their expectations, and when expectations are not exceeded, the customer is discontented and may not use the services again. On the other hand, a satisfied customer, that is, if he reaches his expectations, he will probably resort to the service again, and when the expectations are exceeded, the customer is delighted (Kotler \& Keller, 2006). Consumer satisfaction is the primary factor in creating the company's competitive advantage, when the activity or service exceeds customer expectations (Woodside, Frey \& Daly, 1989). According to investigations carried out, satisfaction is the primary factor for customer loyalty (Shankar, Smith, \& Rangaswamy, 2003). Accordingly, retaining and expanding the number of loyal customers, as well as creating actions in order to increase that same satisfaction are factors of high importance for companies that operate online. According to Folstad et al. (2010), ease of use and utility of the process are factors with an impact on customer satisfaction and consequent on customer loyalty in the context of e-commerce.

\section{Customer loyalty}

Customer loyalty is a term with relevant relevance in terms of literature, given the belief that it contributes to the creation of sustainable competitive advantage and consequent profitability for companies, through the act of buying or communicating with a recommendation about it before others (Zau, 2010). Customer satisfaction is the result of the quality of the service and guaranteeing it increases the probability of the customer becoming loyal. This term has been commonly defined as the action of repeatedly buying goods or services in the same organization (Veloso, Magueta, Fernandes \& Ribeiro, 2017). The positive perception of service quality increases the possibility for customers to be dedicated to supporting, developing and strengthening loyalty behavior (Yuen \& Chan, 2010). The truly loyal customers are those who feel that the company is able to meet their needs much better than other companies, thus excluding the possibility of change (Shoemaker and Lewis, 1999).

Bothe (1996) stated some methods that make it possible to maintain the achievement of loyalty towards its customers, namely: knowing the customer's needs; evaluating competition 
in relation to the ability of others to satisfy and retain customers as well as measuring the degree of customer satisfaction and loyalty.

The emergence and expansion of the Internet, such as electronic commerce, allowed the supply of products or services in an agile and individual way. This new way of doing business has led marketing to reinvent itself, being a more relational marketing, that is, there is a focus on managing customer relationships through a personalized and impersonal relationship, a fact that allows you to respond more easily to the needs of customers and create a lasting relationship and mutual benefits, which can lead to customer loyalty (Brexendorf et al., 2010).

According to several studies, the main factors that lead to customer loyalty online are: price, product quality and performance of fulfillment. The quality of the product is related to third parties, which makes it difficult to change, leaving only the price factor and fulfillment as factors of competitive differentiation (Galego, 2014).

\section{Methodology}

This study aims to assess the satisfaction of Auchan Famalicão's online customers, identifying the attributes and dimensions related to the quality of the e-service and its performance in order to determine which attributes reveal an impact on customer satisfaction, and also obtain a view of this store's ability to attract and retain its customers online. In other words, it is intended to: 1) Assess the degree of satisfaction of Auchan Famalicão's online customers with online services ; 2) Assess the degree of satisfaction with the quality of e-service and its sub-dimensions, as well as perceive the degree of loyalty to the online services of this supermarket; and 3) Analyze whether the quality of e-service (placing and delivery of the order) are determinants of customer satisfaction and whether the quality of e-service and satisfaction are antecedents of the loyalty of Auchan / Auchan Famalicão online customers.
In order to be able to respond to the proposed objectives, a quantitative exploratory research was carried out through the application of questionnaire surveys in which the target population was Drive customers looking for Auchan Famalicão online services. In this sequence, a questionnaire adapted from Galego (2014) was applied to answer the following questions: 1) Are the online consumers of Auchan Famalicão satisfied with the different online services ?; 2) Which eservice variables allow the perception of quality (order and delivery) to perform better ?, 3) Which e-service items (quality of order placement and quality of delivery receipt) with better and worst performance/consumer evaluation)?; 4) What is the consumer preferred product delivery method ?; 5) What is the online service most used by Auchan Famalicão customers ?; and 6) Which product categories are most frequently purchased online at Auchan Famalicão? The Questionnaire was applied directly to customers of Drive Famalicão, during the first half of 2019. In this study, respondents were required to fill out three sections. The first section consisted of a standard demographic profile of respondents. The second section contained the characterization of purchase process. The last section includes the statements of dimensions e-service, customer satisfaction and loyalty. Respondents were asked to use a five-point Likert-type scale (between 1 = 'strongly disagree' and $5=$ 'strongly agree') to record their perceptions. Construct reliability was assessed by using the Cronbach's alpha coefficient. Reliabilities ranged from 0.7 to 0.88 , suggesting that the construct could be used with confidence. In line with the study objectives and the literature review, seven study hypotheses were outlined:

$\mathrm{H}_{1}$ : There are differences in customer satisfaction regarding the attributes of the e-service related to placing the order (availability of stock; delivery time, quality of information, ease of use, website design, privacy and security and guarantee and accountability).

$\mathrm{H}_{2}$ : There are differences in customer satisfaction regarding the attributes of e- 
service quality (fulfillment, efficiency, reliability, privacy, guarantee and accountability).

$\mathrm{H}_{3}$ : There are differences in customer satisfaction regarding the attributes inherent to receiving the order (location, time, product quality, stock availability, ease and communication and price.

$\mathrm{H}_{4}$ : There are differences in the degree of customer satisfaction regarding the three factors (operational, relational and cost) of the e-service.

$\mathrm{H}_{5}$ : The dimensions of the quality of the eservice (placing and receiving the order) have a direct and positive influence on online customer satisfaction.

$\mathrm{H}_{6}$ : The dimensions of the quality of the eservice (placing and receiving the order) have a direct and positive influence on customer loyalty online.

$\mathrm{H}_{7}$ : Customer satisfaction has a direct and positive influence on their loyalty to the online service.

In order to respond to the objective of the study and the research hypotheses, exploratory / descriptive analysis techniques were used with the presentation of graphs and tables of absolute and relative frequency. To measure the intensity of the linear correlation between variables, Spearman's correlation coefficient was used. Additionally, linear regression was used to estimate models that allow identifying the determinants of the behavior of the variables under analysis and the influence between them. In all analysis was considered a significance level of $5 \%$.

\section{Data Analysis and findings}

\section{Demographic Profile}

About ninety (89) individuals participated in the investigation, of which $70.8 \%$ (63) were female. Most individuals who buy online, $69.7 \%$ (62), were aged between 30 and 49 years. As for the distance from the residence to the store, it is verified that in $52.8 \%$ (47) of the cases it is less than $6 \mathrm{~km}$ and that $23.6 \%$ (21) was greater than 10 $\mathrm{km}$. Most individuals, $74.2 \%$ (66) had an income of up to $€ 1400$. The level of education is essentially secondary and higher. As for technological capacity, respondents classified it in most cases as good and / or very good.

\section{Characterization of the online process}

It was found that $50.6 \%$ (45) of the respondents used Auchan's online services exclusively. As for online shopping, the majority, 59.6\% (53), do it once a week and $31.5 \%$ (28) monthly. Regarding the amount spent, it is observed that $65.2 \%$ (58) said they spent between 50 and $100 €$ and $20.2 \%$ (18) between 100 and $150 €$. It was found that the majority of consumers surveyed have a preference for the DRIVE service (collection in the car park) offered by Auchan over other services (Average $=$ 4.25; Median = 5).

\section{Correlation and Regression Analyses}

Table 1 shows the results obtained for the degree of satisfaction with the online shopping experience of Auchan by the surveyed consumers. In general, it can be said that consumers are satisfied in all the items evaluated, since all the average values obtained are higher than three (theoretical expected value) and the median varies between four and five, which means that at least $50 \%$ of the respondents are satisfied or very satisfied. However, the items that stand out are: contacts by employees (Ave $=4.71$ ); compliance with the deadline (Ave $=4.70)$ and comfort and convenience of the service (Ave $=4.69$ ) with the highest levels of satisfaction. On the other hand, the items with the lowest average levels of satisfaction stand out: website design (Ave = 3.69); quality of product information available on the website (Ave $=3.70$ ) and ease of use on the website (Ave = 3.75). It should be noted that the dispersion values are relatively low, which reveals an agreement in response among the respondents. Regarding the way these items that constitute the delivery of the order correlate with customer satisfaction, it is observed through Spearman's coefficients that not all are statistically significant and 
those that are have direct correlations and of low intensity.

Table 1: Characterization of the degree of satisfaction with the online shopping experience of Auchan

\begin{tabular}{|c|c|c|c|c|c|c|c|c|c|}
\hline \multirow{2}{*}{ Item } & \multicolumn{5}{|c|}{ Online purchase frequency } & \multirow{2}{*}{ Average } & \multirow{2}{*}{ DS } & \multirow{2}{*}{ Median } & \multirow{2}{*}{ Correlacior } \\
\hline & MI & IS & IN & $S$ & MS & & & & \\
\hline Convenience & $0,0 \%$ & $0,0 \%$ & $5,6 \%$ & $20,2 \%$ & $74,2 \%$ & 4,69 & 0,58 & 5 & 0,101 \\
\hline Service time & $0,0 \%$ & $0,0 \%$ & $5,6 \%$ & $21,3 \%$ & $73,0 \%$ & 4,67 & 0,58 & 5 & $-0,134$ \\
\hline $\begin{array}{l}\text { Contacts by } \\
\text { employees }\end{array}$ & $0,0 \%$ & $0,0 \%$ & $5,6 \%$ & $18,0 \%$ & $76,4 \%$ & 4,71 & 0,57 & 5 & $0,241^{*}$ \\
\hline $\begin{array}{l}\text { Immediate } \\
\text { availability }\end{array}$ & $2,2 \%$ & $4,5 \%$ & $18,0 \%$ & $31,5 \%$ & $43,8 \%$ & 4,10 & 1,00 & 4 & 0,181 \\
\hline $\begin{array}{l}\text { Compliance with } \\
\text { the deadline }\end{array}$ & $1,1 \%$ & $0,0 \%$ & $3,4 \%$ & $20,2 \%$ & $75,3 \%$ & 4,70 & 0,59 & 5 & $0,212^{*}$ \\
\hline $\begin{array}{l}\text { Ease of use } \\
\text { website }\end{array}$ & $3,4 \%$ & $15,7 \%$ & $16,9 \%$ & $30,3 \%$ & $33,7 \%$ & 3,75 & 1,18 & 4 & 0,101 \\
\hline Website design & $3,4 \%$ & $16,9 \%$ & $15,7 \%$ & $36,0 \%$ & $28,1 \%$ & 3,69 & 1,15 & 4 & 0,002 \\
\hline $\begin{array}{c}\text { Quality of } \\
\text { product } \\
\text { information }\end{array}$ & $2,2 \%$ & $15,7 \%$ & $21,3 \%$ & $31,5 \%$ & $29,2 \%$ & 3,70 & 1,12 & 4 & 0,176 \\
\hline $\begin{array}{l}\text { Monetary } \\
\text { savings }\end{array}$ & $0,0 \%$ & $0,0 \%$ & $21,3 \%$ & $34,8 \%$ & $43,8 \%$ & 4,22 & 0,78 & 4 & 0,188 \\
\hline $\begin{array}{l}\text { Privacy and } \\
\text { security }\end{array}$ & $0,0 \%$ & $0,0 \%$ & $18,0 \%$ & $22,5 \%$ & $59,6 \%$ & 4,42 & 0,78 & 5 & $0,216^{*}$ \\
\hline $\begin{array}{l}\text { Warranties and } \\
\text { accountability }\end{array}$ & $0,0 \%$ & $0,0 \%$ & $16,9 \%$ & $20,2 \%$ & $62,9 \%$ & 4,46 & 0,77 & 5 & 0,165 \\
\hline
\end{tabular}


Figure 1 shows the results obtained for the degree of satisfaction of the subdimensions of the quality of the e-service, the Guarantees (Ave $=4.63$ ), followed by
Fulfillment (Ave $=4,40$ ) and Security (Ave = 4.15). The lowest values are shown by Efficiency (Ave $=3.69$ ) and Reliability (Ave $=3.72$ )

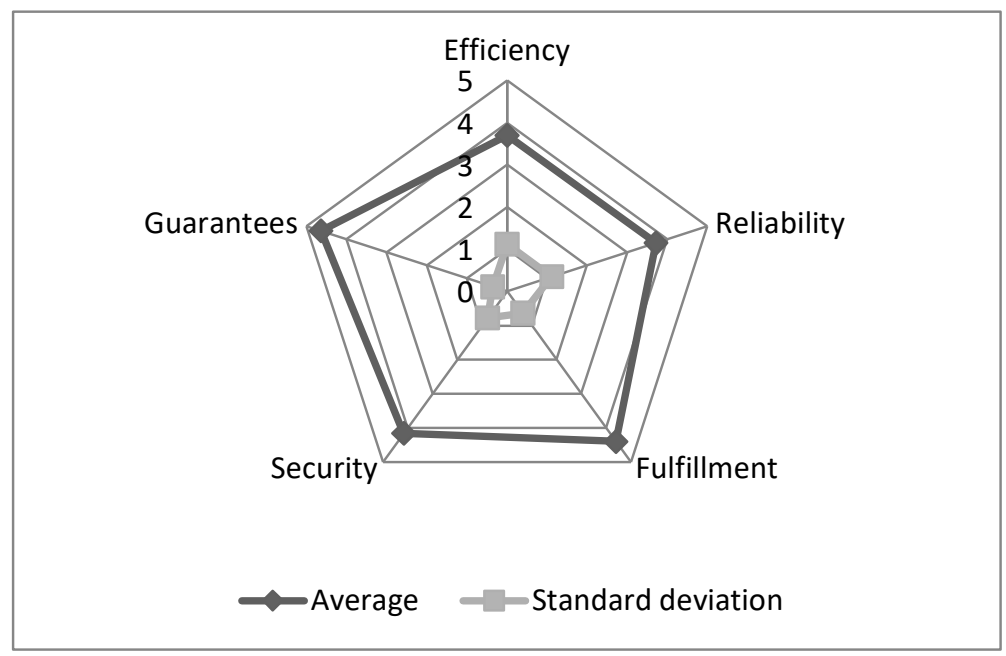

Fig. 1: Degree of satisfaction by sub-dimension of e-service quality

Table 2 shows the results obtained for the degree of satisfaction with Auchan's online delivery processes. In general, it can be said that consumers are satisfied with all the items evaluated, since all the average values obtained are higher than three (theoretical expected value) and the median varies between four and five, which means that at least $50 \%$ of the respondents are satisfied or very satisfied. However, the items that stand out are: delivery time (Ave $=4.82$ ); right product and in good condition (Ave = 4.67) and ease of communication (Ave = 4.62) with the highest levels of satisfaction.
On the other hand, the items with the lowest average levels of satisfaction stand out: place of delivery (Ave $=3.72$ ); service price (Ave $=4.28)$ and products offered (Ave = 4.42). It should be noted that the dispersion values are relatively low, which reveals an agreement in response among the respondents. Regarding the way these items that constitute the delivery of the order correlate with customer satisfaction, it is observed through Spearman's coefficients that not all are statistically significant and those that are have direct correlations and of low intensity. 
Table 2: Characterization of the degree of satisfaction with Auchan's online delivery processes and Spearman's correlation with Satisfaction

\begin{tabular}{|c|c|c|c|c|c|c|c|c|c|}
\hline \multirow{2}{*}{ Item } & \multicolumn{5}{|c|}{ Online purchase frequency } & \multirow{2}{*}{ Average } & \multirow{2}{*}{ SD } & \multirow{2}{*}{$\begin{array}{c}\text { Med } \\
\text { ian }\end{array}$} & \multirow{2}{*}{ Correlacion } \\
\hline & MI & IS & IN & $\mathbf{S}$ & MS & & & & \\
\hline Delivery place & $2,2 \%$ & $20,2 \%$ & $15,7 \%$ & $27,0 \%$ & $34,8 \%$ & 3,72 & 1,21 & 4 & $0,212^{*}$ \\
\hline Delivery time & $0,0 \%$ & $0,0 \%$ & $2,2 \%$ & $13,5 \%$ & $84,3 \%$ & 4,82 & 0,44 & 5 & $0,361^{* *}$ \\
\hline $\begin{array}{l}\text { Right product and } \\
\text { in good condition }\end{array}$ & $0,0 \%$ & $0,0 \%$ & $3,4 \%$ & $25,8 \%$ & $70,8 \%$ & 4,67 & 0,54 & 5 & 0,079 \\
\hline $\begin{array}{l}\text { Replacement of } \\
\text { products }\end{array}$ & $0,0 \%$ & $0,0 \%$ & $6,7 \%$ & $28,1 \%$ & $65,2 \%$ & 4,58 & 0,62 & 5 & $0,260 *$ \\
\hline Products offered & $1,1 \%$ & $0,0 \%$ & $10,1 \%$ & $34,8 \%$ & $53,9 \%$ & 4,42 & 0,72 & 5 & $0,256^{*}$ \\
\hline $\begin{array}{c}\text { Ease of } \\
\text { communication }\end{array}$ & $2,2 \%$ & $2,2 \%$ & $0,0 \%$ & $24,7 \%$ & $70,8 \%$ & 4,62 & 0,75 & 5 & 0,137 \\
\hline Service price & 0,05 & $0,0 \%$ & $7,9 \%$ & $56,2 \%$ & $36,0 \%$ & 4,28 & 0,60 & 4 & $0,278^{* *}$ \\
\hline
\end{tabular}

Figure 2 shows the results of the degree of satisfaction of the delivery of the order distributed by the factors of the quality of the e-service, with the highest value of satisfaction related to relational factors (Ave $=4.62$ ), followed by operational ones (Ave $=4.44$ ) and finally the logistical cost factors (Ave $=4.28$ ).

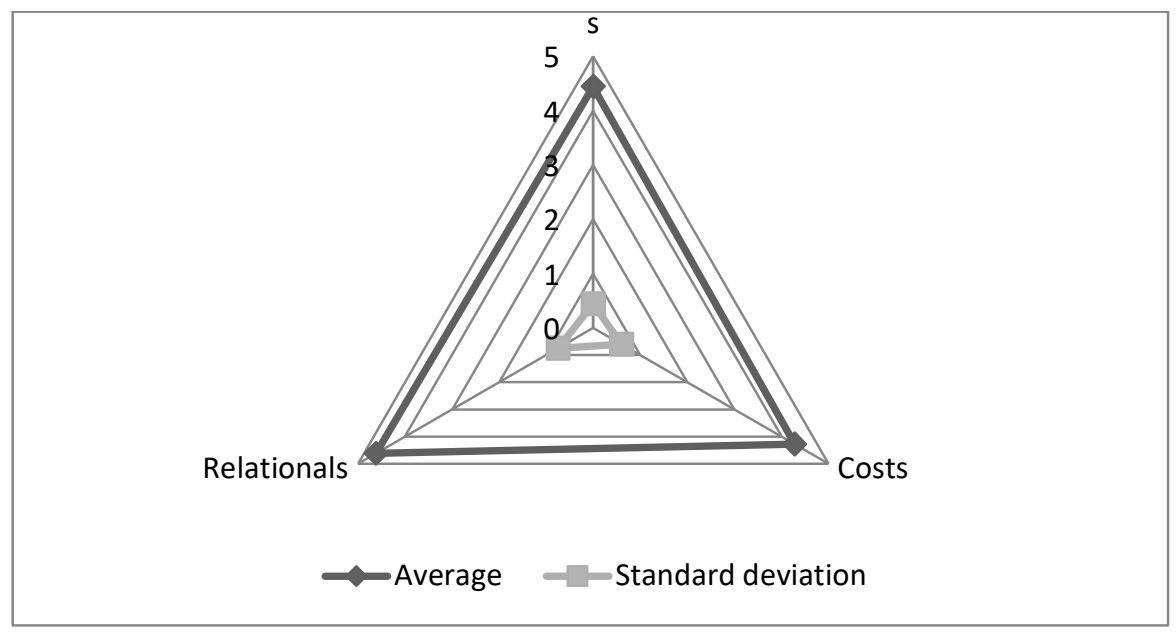

Fig 2. Degree of satisfaction by sub-dimension of e-service

The results obtained demonstrate that the preferred place of delivery of the purchases by consumers is the Drive that is also the most widely used. It is observed that $93.26 \%$ use the drive, but $60.67 \%$ responded that they prefer this place. In reality, $33.71 \%$ of the respondents stated that their preferred place of delivery is the home, but later they end up using the drive. Therefore, it was observed that the delivery 
location coincided with the preferred location in $64.0 \%$ (57) of the cases. It was found that the satisfaction results were statistically identical between the individuals who received the order at the preferred location (Ave $=4.59 ; \mathrm{SD}=0.50$ ) and the individuals who received the order at another location other than the preferred one (Ave = 4.55; SD = 0.57).

As to the reason for using this service, $71.9 \%$ (64) of the respondents referred to the convenience and convenience of the delivery point; $22.5 \%$ (20) responded that it was the fact that the service charge was lower and $5.6 \%$ (5) stated that other delivery points were unavailable.

Regarding the degree of satisfaction with the online services provided by Auchan, table 3 , it is observed that the DRIVE service was used by all respondents and that they are very satisfied (Ave $=4.71$; Ave $=5$ ). The other services were used by few consumers, but they also registered high levels of satisfaction.

Table 3: Characterization of the degree of satisfaction with the online services provided by Auchan

\begin{tabular}{|c|c|c|c|c|c|c|c|c|}
\hline \multirow{2}{*}{ Item } & \multicolumn{5}{|c|}{ Online purchase frequency } & \multirow{2}{*}{ Average } & \multirow{2}{*}{ DS } & \multirow{2}{*}{ Median } \\
\hline & NS & PS & $\mathbf{S}$ & MS & TS & & & \\
\hline $\begin{array}{c}\text { Delivery of } \\
\text { home }(n=18)\end{array}$ & $0,0 \%$ & $0,0 \%$ & $27,8 \%$ & $50,0 \%$ & $22,2 \%$ & 3,94 & 0,73 & 4 \\
\hline $\begin{array}{l}\text { In-store pickup } \\
\quad(\mathrm{n}=3)\end{array}$ & $0,0 \%$ & $0,0 \%$ & $0,0 \%$ & $66,7 \%$ & $33,3 \%$ & 4,33 & 0,58 & 4 \\
\hline DRIVE (n=89) & $0,0 \%$ & $0,0 \%$ & $2,2 \%$ & $24,7 \%$ & $73,0 \%$ & 4,71 & 0,51 & 5 \\
\hline $\begin{array}{l}\text { App Auchan } \\
(\mathrm{n}=26)\end{array}$ & $3,8 \%$ & $0,0 \%$ & $11,5 \%$ & $50,0 \%$ & $34,6 \%$ & 4,15 & 0,78 & 4 \\
\hline
\end{tabular}

As for the loyalty of Auchan's services, Table 4 concluded that the surveyed consumers revealed high levels of loyalty, intend to continue using the services, have positive aspects to mention about the services and intend to recommend the same to others.

Table 4: Characterization of the loyalty of Auchan online services

\begin{tabular}{|c|c|c|c|c|c|c|c|c|}
\hline \multirow{2}{*}{ Item } & \multicolumn{5}{|c|}{ Online purchase frequency } & \multirow{2}{*}{ Average } & \multirow{2}{*}{ DS } & \multirow{2}{*}{ Median } \\
\hline & I & PP & NINP & MP & C & & & \\
\hline $\begin{array}{l}\text { Intention to } \\
\text { return }\end{array}$ & $0,0 \%$ & $0,0 \%$ & $4,5 \%$ & $5,6 \%$ & $89,9 \%$ & 4,85 & 0,47 & 5 \\
\hline $\begin{array}{c}\text { I would say } \\
\text { positive aspects } \\
\text { about services }\end{array}$ & $0,0 \%$ & $0,0 \%$ & $4,5 \%$ & $14,6 \%$ & $80,9 \%$ & 4,76 & 0,52 & 5 \\
\hline $\begin{array}{c}\text { Would } \\
\text { recommend } \\
\text { Auchan online } \\
\text { services }\end{array}$ & $0,0 \%$ & $0,0 \%$ & $4,5 \%$ & $28,1 \%$ & $67,4 \%$ & 4,63 & 0,57 & 5 \\
\hline
\end{tabular}

The majority, $98.9 \%$ (88), of the respondents believe that the service fee pays for the entire purchase process. Table 5 shows the internal consistency of the dimensions of the scale used. Values above acceptable are verified, even being considered good. The placement of the order has a reasonable consistency, the reception of the same shows a low correlation and the issues inherent to the 
customer's loyalty present a good consistency of the values.

Table 5: Scale dimensions composition and internal consistency

\begin{tabular}{|l|c|c|}
\hline \multicolumn{1}{|c|}{ Dimension } & Indicators of scale & $\begin{array}{c}\text { Alpha Cronbach } \\
\text { dimension }\end{array}$ \\
\hline 1 - Placement of order & 6.1 a 6.11 & 0,775 \\
\hline 2 - Reception of order & 7.1 a 7.7 & 0,671 \\
\hline 4- Customer Loyalty & 12.1 a 12.3 & 0,882 \\
\hline
\end{tabular}

By analyzing Table 6, it was concluded that the correlations between the dimensions under study are of low intensity, with the exception of the coefficient obtained between placing and receiving the order that has moderate intensity. All coefficients are positive, which indicates direct correlations between variables. Between loyalty and satisfaction, the coefficient obtained is not statistically significant.

Table 6: Spearman correlation coefficients between dimensions

\begin{tabular}{|c|c|c|c|c|}
\hline & $\begin{array}{c}\text { Placement of } \\
\text { order }\end{array}$ & $\begin{array}{c}\text { Reception of } \\
\text { order }\end{array}$ & $\begin{array}{c}\text { Customer } \\
\text { Loyalty }\end{array}$ & $\begin{array}{c}\text { Customer } \\
\text { Satisfaction }\end{array}$ \\
\hline $\begin{array}{c}\text { Placement of } \\
\text { order }\end{array}$ & 1 & $0,593^{* *}$ & $0,363^{* *}$ & $0,218^{*}$ \\
\hline $\begin{array}{c}\text { Reception of } \\
\text { order }\end{array}$ & & 1 & $0,250^{*}$ & $0,342^{* *}$ \\
\hline $\begin{array}{c}\text { Customer } \\
\text { Loyalty }\end{array}$ & & & 1 & 0,122 \\
\hline $\begin{array}{c}\text { Customer } \\
\text { Satisfaction }\end{array}$ & & & & 1 \\
\hline
\end{tabular}

${ }^{*}$-significative to $5 \%$; ${ }^{* *}$ - significative to $1 \%$.

In general, it can be said that the users of the service were satisfied. Looking at Table 7, it can be seen that in the ordering, placing and receiving processes, the average values obtained are higher than 4 points, which indicates satisfaction with these services. These results certainly influence the overall satisfaction of the customer with the service point, whose average obtained was 4.57 points, a value very close to the maximum possible (5 points). It should be noted that the average level of customer loyalty in this service is also very high, 4.75 points.

Table 7: Characterization of dimensions

\begin{tabular}{|c|c|c|c|c|}
\hline & Minimum & Maximum & Average & $\begin{array}{c}\text { Standard } \\
\text { deviation }\end{array}$ \\
\hline $\begin{array}{c}\text { Placement of } \\
\text { order }\end{array}$ & 3,27 & 5,00 & 4,28 & 0,48 \\
\hline $\begin{array}{c}\text { Reception of } \\
\text { order }\end{array}$ & 3,14 & 5,00 & 4,44 & 0,43 \\
\hline $\begin{array}{c}\text { Customer } \\
\text { Loyalty }\end{array}$ & 3,00 & 5,00 & 4,75 & 0,47 \\
\hline $\begin{array}{c}\text { Customer } \\
\text { Satisfaction }\end{array}$ & 3,00 & 5,00 & 4,57 & 0,52 \\
\hline
\end{tabular}

The application of the multiple linear regression model, Table 8 allowed to obtain a parsimonious model that makes it possible to predict the dependent variable from a set of independent variables. The first regression model presented tests the influence of placing and receiving orders on the variation in customer satisfaction. 
The model obtained has a significance level of $1 \%$ statistical significance, that is, the variation in customer satisfaction is explained significantly by the estimated model. By applying the t test, it is concluded that the receipt of the order $(\beta=0.412 ; p$ values $<0.01$ ) significantly determines the behavior of customer satisfaction. The order placement variable has no significant influence on the variation in customer satisfaction. The estimated model explains, on average, about $14.5 \%$ of the variation in customer satisfaction. The estimated model 2 relates customer loyalty to the variables: order placement, order receipt and customer satisfaction; it is at a significance level of $5 \%$ statistically significant. The determinant of the model that significantly influences the variation in customer loyalty was by the test: placing the order with a coefficient $\beta=0.377$ and $p$ value $<0.01$. The estimated model explains, on average, about $12.5 \%$ of the variation in customer loyalty.

Table 8: A summary of Regression Models

\begin{tabular}{|c|c|c|c|c|c|}
\hline $\begin{array}{c}\text { Dependent } \\
\text { variable }\end{array}$ & Independent variables & $\begin{array}{c}\text { Adjust } \\
\text { ed } R^{2}\end{array}$ & $\begin{array}{c}F \text { value } \\
\text { (p value) }\end{array}$ & $\begin{array}{c}\text { Standardized } \\
\text { coefficients }\end{array}$ & $\begin{array}{l}t \text { value (p } \\
\text { value) }\end{array}$ \\
\hline \multirow{3}{*}{$\begin{array}{c}\text { Customer } \\
\text { Satisfaction }\end{array}$} & Constant & \multirow{3}{*}{0,145} & \multirow{3}{*}{$\begin{array}{c}8,451 \\
(0,000)\end{array}$} & $2,384^{* * *}$ & $4,176(<0,001)$ \\
\hline & Placement of order & & & $-0,011$ & $-0,094(0,925)$ \\
\hline & Reception of order & & & $0,412^{* * *}$ & $3,423(0,001)$ \\
\hline \multirow{4}{*}{$\begin{array}{l}\text { Customer } \\
\text { Loyalty }\end{array}$} & Constant & \multirow{4}{*}{0,125} & \multirow{4}{*}{$\begin{array}{c}4,051 \\
(0,010)\end{array}$} & $3,383^{* * *}$ & $5,824(<0,001)$ \\
\hline & Placement of order & & & $0,377^{* * *}$ & $3,044(0,003)$ \\
\hline & Reception of order & & & $-0,042$ & $-0,319(0,750)$ \\
\hline & Customer satisfacion & & & $-0,004$ & $-0,033(0,974)$ \\
\hline
\end{tabular}

\section{Conclusion}

Currently, the measurement of online customer satisfaction by retailers participating in online commerce is essential to assess the qualification of the service provided, the existing physical infrastructures and the quality of the service, and also to identify causes of dissatisfaction and organizational inefficiencies (Costa \& Ruiz, 2011). Therefore, this investigation aimed to assess Auchan Famalicão's online customer satisfaction and loyalty. The results obtained show that the customers of the Drive service at this store are globally satisfied with the services provided by this retailer. This can be justified, given the lack of competition, in the city under study regarding the DRIVE service. However, the attributes: employee contacts, meeting the delivery deadline, comfort and convenience of the service stand out for the high satisfaction they present. On the contrary, the design of the website, the ease of use of the website and the quality of the information available on the website are the items with the lowest rating by customers. Regarding the sub-dimensions of the quality of the electronic service, there is greater satisfaction in the response capacity and guarantees, followed by compliance, on the other hand, reliability is the sub-dimension that needs to be improved. This study is in line with the results presented by the study by Galego (2014) and by Wolfinbarger and Gilly (2003), who stated that compliance was one of the sub-dimensions of the quality of the electronic service, which brings satisfaction. Regarding the attributes of receiving the order, there are also values in all items, higher than the theoretical value expected, however, the delivery time, the right products and in good condition and the ease of communication present greater associated satisfaction and place of delivery. Delivery stands out by the negative. Regarding the performance factors of the eservice, all present high values, highlighting the relational factors. Operational factors that, according to the literature, are the most important carriers, have high value (4.44).

Through this research it was noticed that, in general, customers are satisfied and loyal with the service under study. However, it was concluded that the attribute of the electronic service with the highest degree of satisfaction is the responsiveness and guarantees, and compliance also has a high degree of satisfaction. On the contrary, the 
attributes of the electronic service: efficiency and reliability showed substantially lower values. The items, ease of use of the website, website design and quality of information about the products showed the least appreciation by the customer. In this sequence, it is observed that the items with less satisfaction are associated with the site, being able to affirm that it needs to undergo some changes, namely, to become more appealing, intuitive and highlight the information about the products that customers really want. These measures would improve customer satisfaction and loyalty and, therefore, the profitability and sustainability of this service. In addition, in the items inherent to the size of the order placement, the delivery location is notable, due to its small size and space with little coverage, which is inconvenient, both for customers and for employees, on days of greater precipitation, checking a customer's discontent and even failure. Thus, suggesting the increase in the size of the space allocated to the service, as well as the implementation of a cover from the entrance of the gallery to the place destined for the service.

It is possible to affirm that studies of this nature are of immeasurable importance, since they allow determining the degree of customer satisfaction in relation to the various associated attributes, as well as the causes responsible for the impact on customer satisfaction, loyalty and involvement in the online service and the redefinition of organizational strategies to fill these gaps. To this extent, the present investigation made it possible to identify the level of satisfaction of Auchan Famalicão's DRIVE service online customers, as well as to identify the dimensions related to their satisfaction and loyalty. This work also contributed to the identification of factors that influence customer satisfaction and loyalty and which require intervention by management bodies. It should also be noted that the priorities must be defined and intervened in terms of the quality of the electronic service provided to customers, in order to increase their satisfaction and loyalty to this commercial store in Famalicão and, consequently, achieve better performance while strengthening their competitiveness and sustainability.
This work was financially supported by the research unit on Governance, Competitiveness and Public Policy (UIDB/04058/2020), funded by national funds through FCT - Fundação para a Ciência e a Tecnologia.

\section{References}

- Abd-El-Salam, E. M., Shawky, A. Y. and El-Nahas, T. (2013), "The impact of corporate image and reputation on service quality, customer satisfaction and customer loyalty: testing the mediating role. Case analysis in an international service company", Journal of Business and Retail Management Research 8 (1), 130-153.

- Bothe, K. (1996) Beyond customer satisfaction to customer loyalty, American Management Association.

- Brexendorf, T.O., Mühlmeier, S., Tomczak, T. and Eisend, M. (2010), "The impact of sales encounters on brand loyalty", Journal of Business Research 63 (11), 1148-1155.

- Costa, S. C. and Ruiz, J. S. (2011), "Comércio Eletrônico", Revista Eletrônica Novo Enfoque 13 (13), 150157.

- Disfani, O., Mantrala, M., Yusta, A. and Ruiz, M. (2017), "The impact of retail store format on the satisfaction-loyalty link: Na empirical investigation", Journal of Business Research Volume $77,14-22$.

- Durvasula, S. and Lysonski, S. (2010), "Diagnosing service quality in retailing: the case of Singapore", Journal International Business and Entreprenurship Development 5 (1), 217.

- Galego, M., (2014) “Desenvolvimento do e-service no retalho eletrónico". Dissertação de mestrado em Gestão. ISCTE Lisboa.

- Herington, C. and Weaven, S. K. (2009), "E-retailing by banks: E-service quality and its importance to customer satisfaction", European Journal of Marketing 43 (9/10), 1220-1231. 
- Hofacker, C. F., Goldsmith, R. E.; Bridges, E. and Swilley E. (2007), Eservice: A Synthesis and Research Agenda.

- Huete, L. (1998) Serviços \& Lucro, Edições AESE, Lisboa.

- Khare, A., Parveen, C. and Rai, R. (2010), "Retailer behavior as determinant of service quality in Indian retailing", Journal of Retail \& Leisure Property 9 (4), 303-317.

- Kotler P. and Keller, K. (2006), Administração de Marketing, 12 edição, São Paulo: Pearson Prentine Hall.

- Martinelli, E. and Balboni, B. (2012), "Retail service quality as a key activator of grocery store loyalty", The Service Industries Journal 32(14), 2233-2247.

- Mansano, A. T. and Gorni, P. M. (2014), "Satisfação do Consumidor com o Comércio Eletrônico: Estudo de Caso de uma Fabricante de Tapetes", Revista de Extensão e Iniciação Científica SOCIESC - REIS, 1 (1), 12-22.

- Moura, G. M. (2006), Encontros de Serviços e satisfação de clientes em hospitais. Dissertação pós-graduação. Universidade federal do Rio de Grande do Sul. Rio Grande do Sul.

- Parasuraman, A., Berry, L. L. and Zeithaml V. A. (1988), "Servqual: A Multiple- Item Scale for Measuring Consumer Perceptions of Service Quality", Journal of Retailing 64 (1), 1240.

- Parasuraman, A., Zeithaml, V. A. and Berry, L. L. (1994), "Reassessment of expectations as a comparison standard in measuring service quality: implications for further research", The Journal of Marketing 58(1), 111-124.

- $\quad$ Rao, S., Goldsby T. J.; Griffis S. E. and Iyengar, D. (2011), "Electronic Logistics Service Quality (e-LSQ): Its Impacto $\mathrm{n}$ the Customer's Purchase Satisfaction and Retention", Journal of Business Logistics, 32, 167-179.
- $\quad$ Rao, S.; Griffis, S. E. and Goldsby, T. J. (2011), "Failure to deliver? Linking online order Fulfillment glitches with future purchase behavior", Journal of Operation Management, 29, 682-703.

- Rabinovich E. and Evers, P. T. (2003)/2007, "Product Fulfillment in Supply Chains Supporting InternetRetailing Operations", Journal of Business Logistics 24 (2), 205-236.

- Santos, J. (2003) "E-service quality: a model of virtual service quality dimensions", Internet Research 15 (1), p. 21-48.

- Shankar, V., Smith, A. K., and Rangaswamy, A. (2003), "Customer satisfaction and loyalty in online and offline environments", International Journal of Research in Marketing 20(2), 153-175

- Shoemaker, S. and Lewis, R. (1999), "Customer loyalty, the future of hospital marketing", Hospitality Management 18, 345-370.

- $\quad$ Tang, Y., Stanworth, J., Chen, W., Huang, S. and Wu, H. (2015), "Toward a measure of Chinese hypermarkt retail service quality", Total Quality Management 26 (3), 327-338.

- Vavra, T. G. (1996), Marketing de relacionamento; after marketing, São Paulo, ed. Atlas

- Veloso, C. M., Magueta, D., Fernandes, P. and Ribeiro, H. (2017), "The Effects of Customer Satisfaction, Service Quality and Perceived Value on Behavioural Intentions in Retail Industry", Proceedings of the $23^{\text {rd }}$ International Scientific Conference on Economic and Social Development, 15-16 September, Madrid, Spain, 330-342.

- Wolfinbarger M. and Gilly, M. (2003), "eTailQ: Dimensionalizing, Measuring and Predicting Quality", Journal of Retailing 79, 183-198.

- Woodside, A. G., Frey, L. L. and Daly, R. T. (1989), "Linking Service quality, customer satisfaction and behavioral intention", J. Healthcare Mark 9 (4), 517. 
- Yu, W. and Ramanathan, R. (2012), "Retail service quality, corporate image and behavioural intentions: the mediating effects of customer satisfaction", The International Review of Retail, Distribution and Consumer Research 22 (5), 485-505.

- Yuen, E. F. and Chan, S. S. (2010), “The Effect of Retail Service Quality and Product Quality on Customer", Journal of Database Marketing \& Customer Strategy Management 17(3), 222-240.

- Zau, J. L. (2010), “O estudo da satisfação e dos determinantes de lealdade dos clientes bancários: um estudo entre estudantes universitários", Universidade de Coimbra, Coimbra.

- Zeithaml, A., Berry, L. and Parasuraman, A. (1996), "The Behavioral Consequences of Service Quality", Journal of Marketing 60 (2), 31-46.

- Zeithaml, A. V., Parasuraman, A. and Malhotra A. (2002), "Service Quality Delivery Through Web Sites: A Critical Review of Extant Knowledge", Journal of the academy of Marketing Science 30 (4), 362-375. 